\title{
Contributors
}

\section{Hans Bleeker}

Teaches at the University of Utrecht and is engaged in phenomenological research into children's experience of place and space. He is co-author (with Karel Mulderij) of Kinderen Buiten Spel (about child-friendly living spaces in urban neighbourhoods) and Kinderen Wonen Ook (suggestions for improving living environments for children).

\section{Eric Burt}

Principal of Saulteaux Heritage School, Cochin, Saskatchewan. He was recently granted a Ph.D. in Secondary Education at the University of Alberta on a dissertation study entitled Utopian Prospects for a Critical Social Studies in the Late Twentieth Century State.

\section{Lea Dasberg}

Professor in the History of Education at the University of Amsterdam. As a reaction to Ariès, she wrote a book about the social position of children in history $(1975,9$ th Dutch edition 1983), introducing the theory of "youthland as an historical phenomenon"; youthland is the protected world of childhood between the Enlightenment and the Second World War. In 1981 she published a book about children's literature as a reflection of the changing concepts of childhood. She also wrote about Peace Education and the changing problems of adolescence. Her present research on "Utopia and Education" is to find a theory of the meaning of a perspective in education.

\section{Martinus Jan Langeveld}

Professor Emeritus of Pedagogy, of General Didactics, and of Developmental Psychology at the University of Utrecht, Holland. He is the author of dozens of books and numerous articles. Some of his best known books include Beknopte Theoretische Pedagogiek (A Concise Theoretical Pedagogy), Erziehung und Wirklichkeit (Education and Reality), Die Schule als Weg des Kindes (The Meaning of the School as a Place for the Child's Becoming), Elk kind is er Een (Every Child is One).

\section{Wilfried Lippitz}

Professor of Education at Universität-Gesamthochschule, Siegen, West Germany. His writings have dealt with educational theory, philosophy of education, especially phenomenologically oriented theory of learning and schooling. His most recent books are "Lebenswelt" oder die Rehabilitierung vorwissenschaftlicher Erfahrung (1980), with J. Plaum: Tasten-Gestalten-Genieben (1981), with K. Meyer-Drawe: Lernen und sein Horizonte (1982). Lippitz has founded the "Arbeitskreis für phänomenologisch-pädagogische Forschungen."

\section{Dieter Misgeld}

Associate Professor of Philosophy in Education at the Ontario Institute for Studies in Education (University of Toronto). He has studied in Heidelberg with H. G. Gadamer and his writings deal with foundations for an interpretive social science and critical social theory. His interest is in phenomenology, hermeneutics, and critical social theory in relation to contemporary education as a form of societal rationalization.

\section{Karel Mulderij}

Teaches at the University of Utrecht and is doing research into children's experience of space. He is co-author of Beleving en Ervaring (Experience and Lived Experience) with Ton Beekman; Kinderen Buiten Spel (about child friendly living spaces in urban neighbourhoods) and Kinderen Wonen Ook (suggestions for improving living environments for children) with Hans Bleeker.

\section{Wilfred H. O. Schmidt}

Professor Emeritus of Educational Psychology at the University of Alberta. With his Ph.D. in psychology from Leipzig. University (Germany), the major part of his career in teacher education has been at the University of Natal in South Africa and, since 1966, at the University of Alberta. Author of Child Development: The Human, Cultural, and Educational Context (1973) and papers on human development in a cross-cultural perspective. 


\section{Svi Shapiro}

Assistant Professor in the Social Foundations of Education at the University of North Carolina at Greensboro. His research concerns the relation between education,

ideology and the State in capitalist society, and the influence of cultural change on educational practice. His most recent publication is "Class, Ideology and the Basic Skills Movement: A Study in the Sociology of Educational Reform," Interchange (Vol. 14, No. 2, 1983).

\section{Max van Manen}

Professor of Education at the University of Alberta; he has taught school in the Netherlands and in Canada. He was an assistant professor at the University of Toronto, Ontario Institute for Studies in Education and he holds a Ph.D. from the University of Alberta. Max van Manen has published in the areas of social education, research methodology, curriculum theory and phenomenology and pedagogy. He is associated with various journals and he is founding editor of Phenomenology + Pedagogy.

\section{Walter Werner}

Associate Professor of Social and Educational Studies at the University of British Columbia, Vancouver. His research and writings have dealt with educational change, critical methodology, and quality of life. 


\section{Human Science Research Conference}

\section{Announcement and Call for Papers}

The 3rd annual Human Science Research Conference will be held at West Georgia College, Carrollton, Georgia, May 16-19, 1984. The aim of this conference is to provide those engaged in human science research the opportunity to meet and share their work. The term "human science" is meant broadly to indicate a spirit of fidelity to the uniqueness of human existence as one's subject matter, and the taking into account of that uniqueness in one's approach and methodology. Presentations may report results of qualitative, descriptive, phenomenological research; or they may examine pertinent theoretical issues. Proposals for presentations must be received by February 1. For further information write to: Dr. Mike Arons, HSR Conference Coordinator, Psychology Department, West Georgia College, Carrollton, Georgia, 30118.

\section{Dissertation Reviews}

The Dissertation Review Editor invites submission of doctoral research which is of high quality and which engages topics of general interest to the journal. For preliminary review, a copy of the dissertation's Abstract, Table of Contents, and Introduction (or Chapter One) should be sent to Dr. David G. Smith, Dissertation Review Editor, St. Thomas University, Fredericton, New Brunswick, Canada E3B 5G3.

\section{Forthcoming Issues}

Phenomenology + Pedagogy, Volume 1, Number 3, 1983, will feature articles based on "The Study of Children's Culture" project. Conducted by Alan Blum, Peter McHugh, and Associates.

Phenomenology + Pedagogy, Volume 2, Number 1, 1984, will contain articles on the theme "Teaching Phenomenology".

The editors of Phenomenology + Pedagogy invite relevant articles, Book Reviews, and Dissertation Reviews. Authors are requested to submit copies in triplicate and adhere to APA style. 